\title{
South African teachers' exposure to workplace bullying
}

\author{
CDE WET AND LJACOBS $S^{2}$
}

\begin{abstract}
Research on workplace bullying (WPB) in occupations, identified teaching as a high risk job. Yet there is a dearth of research on WPB among teachers. The aim of this study is to contribute to the limited body of knowledge on the prevalence of WPB within an international and South African schooling context. This article reports on results from an exploratory study on South African teachers' exposure to WPB. Self-reporting questionnaires were completed by a convenient, voluntary sample of teachers $(n=999)$. The respondents had to indicate their exposure to 43 pre-defined acts of WPB clustered into four categories. This study exposes the commonness of WPB among participating teachers: $90.8 \%$ of them were victims of WPB during the 12 months that preceded the study, and $89.1 \%$ of the victims had been exposed to at least two different categories of WPB. The perpetrators tried especially to undermine the victims' professional status and isolate them. The study identified the constant evaluation of victims' performance as the most common of the 43 negative acts. The results are discussed with reference to other studies. It is concluded that WPB is a serious problem in South African schools and needs to be addressed on policy and institutional levels.
\end{abstract}

Key words: educators, mobbing, South Africa, survey, workplace bullying

Disciplines: criminology, education studies, industrial psychology

\section{Introduction}

Increasing attention has been devoted to the concept of workplace bullying (WPB) during the past 20 years. Various factors, ranging from personality traits to organisational factors, have been studied as possible antecedents to WPB (Blasé \& Blasé, 2004a:251; De Wet, 2010:1451; Hauge, Skogstad \& Einarsen, 2007:220, 2010:427; Moayed, Daraiseh, Shell \& Salem, 2006:311; Salin, 2003:1221). Researchers also studied personal (e.g. humiliation,

1. Corene de Wet $(\mathrm{PhD})$ is Professor of Education at the School of Open Learning, University of the Free State. She researches on issues of bullying in schools. Email: dewetnc@ufs.ac.za.

2. Lynette Jacobs $(\mathrm{PhD})$ is Head of the School of Education Studies at the University of the Free State. Her research focus is on issues of policy and bullying in schools. Email: jacobsl@ufs.ac.za.

TD The Journal for Transdisciplinary Research in Southern Africa, 9(3), Special edition, December 2013, pp. 446464. 
devaluation, discrediting, degradation, depression and cardiovascular diseases - De Wet, 2010:1456; De Wet, 2011:66-76; Duffy \& Sperry, 2007:398; Malinauskienë, Obelenis \& Đopagienë, 2005:20; Moayed et al., 2006:312), organisational (e.g. high turnover, absenteeism, reduced loyalty, apathy and mediocrity - Blasé \& Blasé, 2004a:251; De Wet, 2010:1456; De Wet, 2010:1456) and economic (direct and indirect financial costs - Blasé \& Blasé, 2004a:251; McCormack, Casimir, Djurkovic \& Yang, 2009:2107) consequences of WPB.

Whereas numerous international publications (e.g. Blasé, Blasé \& Du, 2008:264; Hauge et al., 2010:427; Jennifer, Cowie \& Ananiadou, 2003:490; Malinauskienë et al., 2005:20-25; Momberg, 2011:24-41) shed light on WPB since the initial studies under the leadership of Heinz Leymann in Sweden in the late 1980s (Zapf \& Einarsen, 2001:370), De Wet (2011:66), Cunniff \& Mostert (2012:2), as well as Momberg (2011:41) have found that research on the topic within the South African context is limited.

Susan Marais-Steinman first created awareness of WPB in South Africa in the regional newspaper The EastRander in July 1994 (Momberg, 2011:41). With the exception of a few research projects partially devoted to workplace violence in the health sector, Momberg (2011:41) has found virtually no evidence of research on WPB in South Africa during the $20^{\text {th }}$ century. Marais-Steinman is known for her pioneering work on WPB in the South African context across occupations (1998) and in the health sector (2003). Naidoo's (2000) article gives an overview of the symptoms of victims of workplace bullying and suggests guidelines for addressing the problem on a personal and organisational level. Burton (2001) discusses workplace bullying as a subset of workplace violence. Phenomenological studies by Pietersen (2007) and Denton and Van Lill (2007) focus on bullying in academia and industry respectively. From a Labour Law perspective, Momberg (2011) investigated the reliability of using grievance reporting as an indication of WPB trends in the South African public service. $\mathrm{He}$ acknowledges the limitations of such reporting and highlights the shortcomings of existing labour laws in dealing with WPB. Upton (2010:24) studied the impact of WPB on individual and organisational well-being in a large South African construction company. Cunniff and Mostert (2012:2) surveyed the prevalence of workplace bullying among employees in six sectors in South Africa: financial, mining, government, manufacturing, academic and call centres. A reading of the WPB literature thus indicates a need for further research on WPB among South African employees.

No sector of the labour force is immune to WPB (Jennifer et al., 2003:498; McCormack et al., 2009:2108). Notwithstanding a scarcity of publications on WPB in schools (Zapf, Escartin, Einarsen, Hoel \& Vartia, 2011:90-96), studies on WPB across occupations has shown an over-representation of persons from the teaching profession in countries such as the UK, Sweden, Norway, Ireland and Australia (cf. Fahie \& Devine, 2012:2; Leymann, 1996:176).

After an extensive literature search only a small number of studies that focus WPB in schools have been identified (cf. also Zapf al.'s 2011:90-96 list of publications on WPB). Blasé and Blasé's (2004b) large qualitative study (interviews with 50 teachers) in the USA focused on principals' abusive behaviour towards teachers. This study was followed by a study in which 172 USA teachers were surveyed through the use of a self-administered questionnaire offered on the website of the National Association for the Prevention of Teacher Abuse (Blasé et al., 2008:264). Malinauskienë et al. (2005:21) used the Negative Acts Questionnaire (NAQ) (cf. Einarsen, Raknes \& Matthiesen, 1994) to study the prevalence of WPB, as well as its effects 
on cardiovascular diseases on teachers $(n=475)$ in Kaunas city in Lithuania. Russo, Millić, Knežević, Mullić and Mustajbegović (2008:545) developed a questionnaire to study WPB among teachers in Croatia. Using an adapted version of NAQ, Cemaloğlu (2007a:792; 2007b:3) and Ertük (2013:169) studied WPB in Turkish schools. A study by McCormack et al. (2009:2117) focused on the correlation between teachers in China's ( $n=142)$ intention to resign and their exposure to WPB. A study under the auspices of the National Association of Schoolmasters Union of Women Teachers (NASUWT, 2012:5) looked into the prevalence of and consequences of WPB in British schools. A qualitative study by Fahie and Devine (2012:2) investigated the impact of WPB on primary school teachers and principals in Ireland. They interviewed 24 teachers.

The following studies focus on WPB in South Africa schools: Collaboration between educational psychologists and an expert in educational law (Kirsten et al., 2005) resulted in a paper which explores the bullying behaviour of educational leaders with narcissistic personality disorder (NPD) on teachers. Publications by De Wet $(2010 ; 2011)$ emanating from her 2008-interviews with eight teachers who were subjected to supervisor abuse focus on their lived-experiences, whereas Rutherford's (2009) study gives a labour law perspective on various aspects of educator security, including WPB. De Vos's (2013) qualitative phenomenological research explored 27 teachers' experiences of WPB and its effects on their health.

The majority of international studies on WPB were conducted as survey studies measuring respondents' exposure to pre-defined negative behaviours (e.g. Blasé et al., 2008:279; Hauge et al., 2007:231, 2010:429; Nielsen, Notelaers \& Einarsen, 2011:153; Samnani, 2013:26). Nonetheless, with the exception of research by Cunniff and Mostert (2012:2), MaraisSteinman (2003:25), Momberg (2011:52), Upton (2010:57) and Khalil (2009:210), no study could be found that measures the prevalence of bullying among South African employees. The only study that claims to look at the prevalence of WPB in South African schools is that of Momberg (2011:52). Yet, there may be questions concerning the authority of his claim: he used only 15 respondents to establish prevalence rates.

Owing to the lack of research results on the prevalence of WPB, interventions are often based on a generally accepted estimate of the prevalence of bullying in organisations. Tailor-made intervention programmes however, need information that provides finer distinctions on both the frequency and nature of bullying (Momberg, 2011:147; Notelaers, Einarsen, De Witte \& Vermunt, 2006:294; Zapf \& Einarsen, 2001:371). Detailed, quantitative studies of the different types of negative behaviour may help interventionists to apply the hierarchy of intervention measures, such as addressing behaviour deleterious to professional status and causing isolation.

The preceding exposition shows that research across occupations found: teaching to be a high risk job; the negative consequences of WPB on employees and organisations; the lack of research on the topic in South Africa and within an international and South African schooling context; and the need for data on the prevalence of WPB in South African schools. South Africa is facing an education crisis and motivated and dedicated teachers are a prerequisite to "rebuild a faltering school system" (Jansen, 2011:2). This will not be possible if teachers are victimised by their peers, leaders, administrative staff, parents and even learners. Research on the prevalence of WPB in South African schools may inform intervention programmes that could reduce WPB in schools. Based on our exposition of previous research on the topic, in which we highlighted a dearth of research on WPB among teachers in 
general and South African in particular as well as the possible negative consequences of WPB on teachers working in a faltering education system, we argue that there is a need for research on WPB in South Africa in general and within a schooling context in particular. The aim of this study is therefore to contribute to the limited body of knowledge on the prevalence of WPB within the international and South African schooling context. We will, accordingly, provide an overview of South African teachers' ${ }^{\prime 3}$ exposure using four broad categories, as well as specific acts of WPB.

\title{
What is WPB?
}

Einarsen (1999:17) defines WPB as

... all those repeated actions and practices that are directed to one or more workers, which are unwanted by the victim, which may be done deliberately or unconsciously, but clearly cause humiliation, offence, and distress, and that may interfere with job performance and/or cause an unpleasant working environment.

Bullying is about frequent and prolonged exposure to negative acts that are intended to be hostile and/or are perceived as hostile by the victim. It may by triggered by a work-related conflict in which the target becomes increasingly stigmatised, victimised and unable to cope with the situation (Momberg, 2011:21; Notelaers et al., 2006:290; Salin, 2001:1214-1216).

Whereas leading researchers in the field (cf. Einarsen, 1999:17; Smith, Singer, Hoel \& Cooper, 2003:175) use the terms 'bullying' and 'victimisation' interchangeably, the Department of Human Resources (Birkbeck University of London, n.d.) makes the following difference:

\begin{abstract}
Bullying is offensive, intimidating, malicious or insulting behaviour, an abuse or misuse of power which is meant to undermine, bumiliate or injure the person to whom it is directed.

Victimisation is the less favourable treatment of someone compared to their peers because they, in good faith, have complained (whether formally or otherwise) that someone has been bullying or harassing them or someone else, or supported someone to make a complaint or given evidence in relation to a complaint. This would include the isolation of someone because he or she has made a complaint or giving him or her worse work.
\end{abstract}

In this study article we will follow international research treads and use the terms interchangeably.

A wide variety of negative acts that may constitute WPB has been identified by researchers (cf. Agervold, 2007:170; Cunniff \& Mostert, 2012:3; Einarsen, 1999; Nielsen et al., 2011:153; Rayner, Hoel \& Cooper, 2002:195-196; Ozturk, Sokmen, Yilmaz \& Cillingir, 2008:439-440; Yildirim, Yildirim \& Timucin, 2007:452). WPB surveys typically include 22 to 45 items on different negative acts (Agervold, 2007:170; Nielsen et al., 2011:155). The questionnaire used in this study included 43 negative acts. While these acts are often

3 In this study, 'teacher' denotes a person working as a trained teacher in an education environment, and does not refer to any specific post level. When referring to a post-level 1 teacher we use the word 'educator'. 
categorised (Nielsen et al., 2011:154-159), these categorisations are not standardised. The following are examples of such categorisation: Cunniff and Mostert (2012:3) distinguish between direct (face-to-face, interpersonal) and indirect (relational) WPB. Ozturk et al.'s (2008:439) sub-categories include attacks on self-esteem, personal and professional relationships and professional practices, as well as criticism of the victim's personal life (cf. also Einarsen, 1999:18; Nielsen et al., 2011:154-159; Yildirim et al., 2007:452). Most researchers differentiate between work-related and personal-related WPB (cf. Rayner et al., 2001:123-313; Zapf et al., 2011:88). In this study we clustered the 43 negative acts into four categories. The large variety of negative acts identified by researchers, and the different categorisations thereof will be apparent from the following account of research findings on the prevalence of WPB.

\section{The prevalence of bullying}

Notelaers et al. (2006:290) argue that WPB should be seen as a continuum from "not at all exposed" to "highly exposed" and not as an either/or phenomenon. They also found that victims of bullying may be exposed to a wide range of different behaviours, be it in the form of persistent insults or offending remarks, persistent criticism or even personal or physical abuse. According to Einarsen (2000, Notelaers et al., 2006:290) the only common denominator of these behaviours is that these negative behaviours are "used with the aim or at least the effect of persistently humiliating, intimidating, frightening or punishing the victim". The frequency of bullying varies between different studies that use different criteria to decide who is actually a victim and who is not. Different targets of bullying may experience different types of bullying. Researchers furthermore use different categorisations of bullying. Surveys use a variety of response categories: whilst some surveys use a Likert scale, others use specific timelines; for example, never, now and then, monthly, weekly, and daily (cf. Nielsen et al., 2011:157-159; Rayner et al., 2002:196). The timeframes in questionnaires often differ; respondents should for instance, reflect on how often they have been victimised in the preceding three, six or twelve months (cf. Nielsen et al, 2011:157-159). It is therefore, according to Notelaers et al. (2006:290), not surprising that the frequency of bullying varies in different studies. These differences will be obvious from the subsequent exposition of research findings on the prevalence of WPB in South Africa workplaces, and in schools worldwide.

In South Africa, the Internet survey conducted by Marais-Steinmann in 1998-1999 found that 77.8\% of South Africans feel bullied in the workplace (cf. Marais-Steinman, 2003:9). In a study by Marais-Steinman (2003:25) under the auspices of the World Health Organisation health workers $(n=1018)$ reported having experienced incidents of verbal abuse $(49.5 \%)$, workplace bullying (20.4\%), racial harassment (22.3\%) and sexual harassment (4.6\%). A study by Khali (2009:210) on the levels of violence among nurses in Cape Town public hospitals $(\mathrm{n}=471)$ found that $53.5 \%$ of the respondents agreed that there is violence among nurses; $23.78 \%$ were not sure, $13.38 \%$ indicated that there is no violence among nurses, and $9.34 \%$ were nonresponsive. The respondents were also asked to indicate the types of violence that occur in their work environment. The following is a ranking of the six types of violence used in Khalil's (2009:211) survey instrument: psychological violence (45\%), vertical violence (33\%), covert violence (30\%), horizontal violence (29\%), overt violence (26\%) and physical violence (20\%) across all participating hospitals. Upton's (2010:57) statistics on the prevalence of WPB in a large South African construction company show that WPB was rare 
in the company under investigation: $81 \%$ indicated that they had never been bullied, $10 \%$ rarely, $6 \%$ now and then, and 3\% daily. In a survey conducted by Cunniff and Mostert (2012:3) 31.1\% of the 13911 respondents indicated that they were bullied at work. Their study moreover, distinguishes between direct and indirect bullying: $28.4 \%$ and $23.8 \%$ of the respondents were either 'often' or 'always' subjected to direct and indirect WPB respectively. The title of Momberg's (2011:52) study (The prevalence and consequences of workplace bullying in South Africa) creates false expectations, in terms of its generalisability and scope. Three basic questions were put to 15 people. The two questions that may be relevant for this study read as follows: (1) "Indicate the intensity level of workplace bullying in jour organisation using a scale of high, medium and low." (2) "Indicate the frequency level of workplace bullying in your organisation, using a scale of frequent, not so often, or hardly ever." The responses to question 1 were as follows: high: $85 \%$, medium: $15 \%$, low: $0 \%$. The responses to the second question were: frequently: $73.3 \%$, not so often: $26.7 \%$; hardly ever: $0 \%$. Using statistics of grievances reported by public servants in the 2006/2007, 2007/2008 and 2008/2009 financial years he found an escalation of "unfair treatment" grievances reported to the Public Service Commission (PSC): 517 (2006/2007) $\rightarrow 590(+14.1 \%)(2007 / 2008) \rightarrow$ 1154 (+95.59\%) (2008/2009) (Momberg, 2011:84). According to Momberg (2011:145) the PSC “conservatively" estimated that as much of $15 \%$ of "unfair treatment" grievances could be attributed directly to WPB. Although the escalating number of grievances relating to unfair treatment does not reflect the prevalence of WPB in South Africa, it may be indicative of discord among workers in the South African public service.

Whilst Fahie and Devine (2012:2) stated that WPB is a serious problem in schools, only a few publications were identified that specifically study the prevalence of WPB in schools worldwide. The following exposition will give an insight into the major findings of these research studies. To ascertain the prevalence of WPB among 475 Lithuanian teachers Malinauskienë et al. (2005:22) asked the following question: "Have you ever been bullied at work?" The results show that $74.4 \%$ have never, $19.2 \%$ rarely, 3.8\% 'now and then', $1.9 \%$ 'several times a week', and $0.7 \%$ almost daily being victims of WPB. In addition, using the NAQ, Cemaloğlu (2007a:792) found that 50\% of respondents experienced some kind of WPB. The most frequent type of bullying the teachers faced daily was "someone withholding necessary information affecting your performance" (5.8\%). The most frequent bullying behaviour experienced was "being ordered to do work below your level of competence" (43.9\%). The least observed bullying behaviour was "ridicule" (12.8\%). Of the 764 teachers surveyed in Split, Croatia, Russo et al. (2008:545) found that $22.4 \%$ were exposed to and $31.7 \%$ had witnessed acts of WPB in the previous 12 months. NASUWT (2012:5) studied the prevalence of WPB in British schools. They found that $76 \%$ of the respondents $(n=3028)$ either experienced or witnessed WPB. Further analysis by them revealed that $22 \%$ of the respondents had both experienced and witnessed WPB. The followings percentages show the teachers exposure to predetermined acts of WPB (they could select as many as relevant): persistent unjustified criticism (53\%); intimidatory use of discipline/competence procedures (45\%); freezing out, ignoring or excluding (41\%); destructive innuendo/sarcasm (35\%); being set impossible deadlines for work (35\%); being shouted at in the presence of colleagues (32\%); being shouted at in the presence of learners (19\%); areas of responsibility being moved without consultation (18\%); threats (verbal or non-verbal) (17\%); incessant and demanding emails $(17 \%)$; abuse (1\%); cyber bullying (1\%) and violence to property (1\%) (NASUWT, 2012:8). Blasé et al.'s (2008:270) study on the bullying of teachers used a self-administered questionnaire on the website of the National Association for the Prevention of Teacher Abuse. All 172 teachers who completed the questionnaire were victims of WPB. The five 
most common acts of mistreatment for the victims were as follows: "failed to recognise or praise me for work-related achievements" (69.7\%); "favoured 'select' teachers" (62.7\%); "tried to intimidate me" (58.8\%); "failed to support me (i.e. abandoned me) in difficult interactions with students and/or parents" (57\%); and "ignored or snubbed me" (55.2\%) (Blasé et al., 2008:279).

In the discussion of the results of our study we will refer to the above and other research findings on the prevalence of WPB.

\section{Research methodology}

\section{Research approach}

In this study we follow a functionalist paradigmatic approach (Samnani, 2013:26). The functionalist approach is "firmly rooted in the sociology of regulation and approaches its subject matter from an objectivist point of view" (Burrell \& Morgan, 1979, in Samnani, 2013:26). In this study we will, as is typical of functionalism, study the regularities of a phenomena (WPB), use predetermined definitions and behaviours of WPB and emphasise the need for solutions to the problem (Samnani, 2013:29).

\section{Research instrument}

A five-section questionnaire prepared after an extensive literary review and scrutiny of existing WPB questionnaires was used for data collection. In the first section the respondents' demographic information was requested. In the second section questions were asked about their exposure to predetermined acts of WPB; in the third section information was asked about the professional identity of the perpetrators; the fourth addressed the impact of the bullying experience on the respondents; and the last section contained four open-ended questions. This article will focus on the respondents' responses to the second section of the questionnaire. The various items related to teachers' exposure to WPB were presented to the respondents in the form of 43 statements, to which they had to indicate how often they had experienced such acts in the 12 months preceding the study, using a 5-point scale (never, once, occasionally, frequently, constantly). Demographic data will be used to introduce the respondents. Existing WPB literature and questionnaires (cf. Cemaloğlu, 2007a:792; 2007b:3; Einarsen, 1999:18; Rayner et al., 2002:195-196; Yildirim et al., 2007) informed our decision on which behaviours to include in our research instrument. The clustering of these 43 acts into four types/categories of WPB was influenced by Yildirim et al.'s (2007) work. There may be an overlap between these categories/types according to the circumstances in which these behaviours occur (cf. Tables 3-6).

\section{Sample}

A convenient, voluntary sample of teachers who were upgrading their qualifications at the School of Open Learning (SOL), University of the Free State, South Africa, was opportunistically selected. All the teachers who were invited to take part in the study already have a basic education qualification and are employed in some education-related post.

As this is an exploratory study, we do not claim any inferences, but merely seek to provide some understanding about a phenomenon which has received scant attention from 
researchers, namely WPB experienced by South African teachers. Tutors, who facilitate the contact sessions at SOL, provided each of the students enrolled for an education qualification, with a questionnaire. The students had the choice of completing the questionnaire or destroying it. Those who completed the questionnaire were requested, at their convenience, to return it sealed, to the coordinator of the centre where they attended classes.. No record was kept of who returned the completed questionnaire, and this was made clear to the possible respondents at the outset. Of the 2742 questionnaires, 1103 were received back (a return rate of 40.2\%), of which 999 (36.4\%) could be used. The returned questionnaires that were not used were questionnaires on which more than half of the items were not completed.

The final sample of 999 teachers included teachers from all levels of schools, including from preschools (up to grade R) ( $n=21)$, primary schools (Grade R to grade 7) ( $=598)$, intermediate schools (Grade R to grade 9) ( $n=123)$, secondary (Grade 8 to grade 12) $(n=80)$, Further Education and Training schools (Grade 10 to grade 12) $(\mathrm{n}=41)$ and combined schools (grade $\mathrm{R}$ to grade 12) ( $\mathrm{n}=63$ ). Of the respondents, only five indicated that they were teaching at special schools, while 68 gave no indication of the school at which they teach. The schools where the respondents teach are diverse, as can be seen from the geographical classification provided by them: urban area (106), township (264), rural area (505), farm (71), informal settlement (16) and not specified (37) and came from various provinces (Kwa-Zulu Natal: 343; Free State: 434; Eastern Cape: 147; Northern Cape: 35; Gauteng: 33; Mpumalanga: 3; North West: 3 and Western Cape: 1).

Of the 988 respondents who indicated their gender, 143 were male while 845 were female. The age distribution of the respondents at the time of the survey is as follows: 30 years or younger (218); 31 to 40 years (426); 41 to 50 years (256); 51 to 60 years (94); 61 years and older (2) and age not specified (3). The majority of the respondents were post-level 1 educators (911), 22 were heads of departments at their schools, 8 were deputy principals, 23 were principals and 35 respondents did not indicate their post-level.

\section{Research ethics}

The respondents' dignity, privacy and interests were respected at all times. The questionnaires did not contain any identifying aspects, names, addresses or code symbols. Before completing the questionnaires, the respondents were informed that the process was completely voluntary and that they could withdraw at any stage during the process. Each respondent completed an informed consent form. They received no financial or other reward for taking part in the study. Permission for this study was obtained from the Dean of the SOL. Ethical clearance was also obtained from the Faculty of Education, University of the Free State's Ethical Clearance Committee (UFS-EDU-2013-0013).

\section{Capturing and analysis of the data}

An experienced typist captured the data from the questionnaires using MS Excel and spot checks were made for accuracy. The data were analysed, using the STATA IC11 software. In line with the purpose of the paper, we made use of descriptive statistics to establish the prevalence of WPB in schools. When working with a 5-point scale, a score of 3 often serves as a point of neutrality. However, in this study it is not the case, as any score above 1 is an indication that WPB was experienced (and thus, that the respondent was a victim) albeit at 
varying regularities. The higher the score, the more frequently did the victim-respondents experience the specific act.

In order to capture the commonness of the problem, we used the percentage of respondents who indicated that they experience specific types and acts of WPB, irrespective of the frequency with which they experience it (cf. Tables 1 and 3-6). We then explored the intensity with which the victim-respondents experienced the four types and 43 acts of WPB by studying the percentage of victims who frequently or constantly experienced these types and acts of bullying. We collapsed two scales (frequently or constantly) in the statistical analysis and renamed it "regularly" in the Tables 1, and 3-6 (last columns).

\section{Validity and reliability}

In this study, we based our questionnaire on a comprehensive literature review on WPB and existing WPB questionnaires (thus enhancing content validity). The various items related directly to specific constructs that we wanted to measure (working towards construct validity). Before distributing the questionnaires, we gave the instrument to five critical readers for comment, and based on their comments, we improved the face validity of the questionnaire. However, as this is a self-constructed questionnaire that has been used for the first time, there were deficits and we intend to adapt the instrument for usage in future studies (cf. Limitation of the study).

The internal reliability (internal consistency) of the responses was measured by calculating the Cronbach's alpha coefficient. While Nunally in Santos (1999:2) states that a value of 0.7 is generally accepted as indicative of acceptable levels of reliability, Pietersen and Maree (2007:216) argue that an alpha value of 0.9 is indicative of high reliability. In this study, the coefficient for the responses to the 43 scaled items on which this paper is based was calculated to be 0.9662 which suggests a very high level of internal reliability.

\section{Results}

WPB seems to be a widespread problem among the teachers who participated in the study: only 92 of the 999 respondents indicated that they had never experienced any of the 43 listed acts of WPB. This means that $90.8 \%$ of the respondents experienced some form of WPB. The listed acts were categorised in the following types of WPB: behaviour causing isolation; behaviour undermining the professional status of the teacher; behaviour undermining the person; and direct negative behaviour. To expose the extent of the problem, we will firstly report on three issues; namely, how commonly these four broad categories or types of WPB were experienced by the respondents (Table 1); how regularly the victims experienced these four types of WPB (Table 1), and how many different types of WPB were experienced by the victims (Table 2). Secondly, we will focus on specific acts, listed under each of the four types or categories of WPB (Tables 3-6).

In Table 1 the details regarding the percentage of respondents who experienced any one or more of the acts that fall under the particular category of bullying is provided. 
Table 1: Percentage of respondents who experienced different categories/types of WPB

\begin{tabular}{|l|l|l|l|}
\hline & $\begin{array}{l}\text { Number of respondents } \\
\text { who were victims of one } \\
\text { or more act of this } \\
\text { category of WPB } \\
\text { (n=999) }\end{array}$ & $\begin{array}{l}\text { Percentage of } \\
\text { respondents who were } \\
\text { victims of one or more } \\
\text { act of this category of } \\
\text { WPB } \\
\text { (n=999) }\end{array}$ & $\begin{array}{l}\text { Percentage of victims } \\
\text { who regularly* experience } \\
\text { this kind of bullying** }\end{array}$ \\
\hline $\begin{array}{l}\text { Behaviour undermining } \\
\text { professional status. }\end{array}$ & 873 & $83.8 \%$ & $26.8 \%$ \\
\hline $\begin{array}{l}\text { Behaviour causing } \\
\text { isolation. }\end{array}$ & 807 & $80.8 \%$ & $24.5 \%$ \\
\hline $\begin{array}{l}\text { Behaviour undermining } \\
\text { the person. }\end{array}$ & 662 & $66.3 \%$ & $26.0 \%$ \\
\hline $\begin{array}{l}\text { Direct negative } \\
\text { behaviour. }\end{array}$ & 382 & $38.2 \%$ & $22.1 \%$ \\
\hline
\end{tabular}

* Regularly: frequently and constantly on the scale.

**The ' $n$ ' in this column depends on the number of respondents who were victims, thus indicated in column 2 above.

From Table 1 it can be seen that the type of WPB that the respondents most widely experienced is behaviour that undermines their professional status. Of the 999 respondents, $83.8 \%$ indicated that they had experienced one or more acts of this type of WPB, once or more in the preceding 12 months. The second most common type of WPB behaviour that was experienced was behaviour causing isolation. Direct negative behaviour was experienced by fewer victims than the other types of WPB (38.2\%).

The type of WPB that victims most frequently experienced is that of undermining the status of the victim: $26.8 \%$ of the victims, who experienced this kind of WPB, indicated that they are regularly exposed to such acts. Undermining the victim personally is also comparably, a regular problem for victims $(26.0 \%$ of the victims are frequently or constantly exposed to such behaviour). The WPB that is less of a problem in terms of regularity is direct, negative behaviour; $22.1 \%$ of the victims of this type of WPB indicated that they frequently or constantly experience such victimisation.

These insights raised the question whether the same victims are experiencing various categories of WPB, or only one or two. The analysis of the responses of the 907 victims are summarised in Table 2.

Table 2: Number of categories in which respondent-victims indicated that they experienced acts of WPB (n=907)

\begin{tabular}{|l|l|l|}
\hline Number of categories experienced & Number of victims in category & Percentage of victims in category \\
\hline 4 categories & 349 & $38.5 \%$ \\
\hline 3 categories & 275 & $30.3 \%$ \\
\hline 2 categories & 184 & $20.3 \%$ \\
\hline Only 1 category & 99 & $10.9 \%$ \\
\hline
\end{tabular}

Table 2 shows that with the exception of $10.9 \%$ of the victim-respondents, victims of WPB were exposed to more than one type of WPB. A worrying $38.5 \%$ experienced negative acts in all four categories of WPB. 
Table 3 indicates 12 different acts of WPB that cause the isolation of the victim. Based on the responses of the teachers who completed the questionnaire, it presents the different acts ranked from most commonly experienced to least experienced.

Table 3: Respondents who experienced behaviour that causes isolation

\begin{tabular}{|l|l|l|l|}
\hline Act & $\begin{array}{l}\text { Number of } \\
\text { respondents who } \\
\text { were victims } \\
\text { (n=999) }\end{array}$ & $\begin{array}{l}\text { Percentage of } \\
\text { respondents who } \\
\text { were victims } \\
\text { (n=999) }\end{array}$ & $\begin{array}{l}\text { Percentage of } \\
\text { victims who were } \\
\text { regularly* } \\
\text { to act** }\end{array}$ \\
\hline $\begin{array}{l}\text { Behaving as if I am not seen or not there in } \\
\text { the school environment. }\end{array}$ & 464 & $46.4 \%$ & $22.4 \%$ \\
\hline Not answering my request to meet and talk. & 395 & $39.5 \%$ & $18.8 \%$ \\
\hline Interrupting me while speaking. & 384 & $38.4 \%$ & $27.6 \%$ \\
\hline $\begin{array}{l}\text { Silence or hostility as a response to my } \\
\text { questions or attempts at conversations. }\end{array}$ & 380 & $38.0 \%$ & $24.5 \%$ \\
\hline Pressuring me to resign. & 375 & $37.5 \%$ & $31.4 \%$ \\
\hline $\begin{array}{l}\text { Criticising and rejecting my decisions and } \\
\text { recommendations. }\end{array}$ & 365 & $36.5 \%$ & $17.6 \%$ \\
\hline $\begin{array}{l}\text { Withholding information, documents and } \\
\text { material that are necessary for my work. }\end{array}$ & 349 & $34.9 \%$ & $23.5 \%$ \\
\hline Not answering my letters and emails. & 339 & $33.9 \%$ & $20.7 \%$ \\
\hline $\begin{array}{l}\text { Not giving me an opportunity to prove } \\
\text { myself. }\end{array}$ & 275 & $27.5 \%$ & $28.7 \%$ \\
\hline $\begin{array}{l}\text { Not informing me about organised social } \\
\text { meetings. }\end{array}$ & 275 & $27.5 \%$ & $28.4 \%$ \\
\hline $\begin{array}{l}\text { Being inspected by people in a lower } \\
\text { position. }\end{array}$ & 205 & 175 & $24.8 \%$ \\
\hline $\begin{array}{l}\text { Taking work from me that is my } \\
\text { responsibility and giving it to someone in a } \\
\text { lower position. }\end{array}$ & $17.5 \%$ & $32.6 \%$ \\
\hline
\end{tabular}

* Regularly: frequently and constantly on the scale.

**The ' $n$ ' in this column depends on the number of respondents who were victims, thus indicated in column 2 above.

The acts of WPB causing isolation that were experienced by most of the respondents, were others behaving as if the victim was not seen or not there in the school environment $(46.4 \%)$, followed by ignoring requests to meet and talk (39.5\%). The specific act that isolates most victims regularly is depriving them of their responsibilities and giving them to someone in a lower position (32.6\%). This is followed by victims being pressurised to resign (31.5\%). The act that is least recurrently experienced by victims is having their decisions and recommendations criticised and rejected (17.5\%). What is notable, is that some acts, such as behaving as if the victim is not seen, or not there, and not answering requests by the victim to meet and talk, are experienced by a relatively large percentage of the respondents (39.5\%), but those that experience this, seem not to experience it frequently (18.8\%). Other acts, such as having work that is the responsibility of the victims taken away, and given to people in lower positions, are experienced by a few victims (17.5\%), but a large percentage of these victims experience it regularly (32.6\%). Being pressurised to resign is experienced by more than a third of the respondents (375) and $31.4 \%$ of these victims regularly pressurised.

Behaviour undermining the professional status of the teachers was unpacked using 14 items on the questionnaire. Based on the responses of the participating teachers, Table 4 shows the different acts ranked from most commonly experienced to least experienced. 
Table 4: Respondents who experienced behaviour undermining their professional status

\begin{tabular}{|l|l|l|l|}
\hline Act & $\begin{array}{l}\text { Number of } \\
\text { respondents who } \\
\text { were victims } \\
\text { (n=999) }\end{array}$ & $\begin{array}{l}\text { Percentage of } \\
\text { respondents who } \\
\text { were victims } \\
\text { (n=999) }\end{array}$ & $\begin{array}{l}\text { Percentage of } \\
\text { victims who were } \\
\text { regularly* exposed } \\
\text { to act** }\end{array}$ \\
\hline Constantly evaluating my performance. & 541 & $54.2 \%$ & $32.7 \%$ \\
\hline $\begin{array}{l}\text { Making me responsible for more work than } \\
\text { I can manage. }\end{array}$ & 540 & $54.1 \%$ & $32.8 \%$ \\
\hline $\begin{array}{l}\text { Constantly finding mistakes/errors in my } \\
\text { work and in the results of my work. }\end{array}$ & 476 & $47.6 \%$ & $16.6 \%$ \\
\hline $\begin{array}{l}\text { Making me feel as if my work and I are } \\
\text { being inspected. }\end{array}$ & 456 & $45.6 \%$ & $29.8 \%$ \\
\hline $\begin{array}{l}\text { Blaming me for things that are not my } \\
\text { responsibility. }\end{array}$ & 422 & $42.2 \%$ & $23.0 \%$ \\
\hline $\begin{array}{l}\text { Negative reaction from others because I } \\
\text { work "too hard". }\end{array}$ & 420 & $42.0 \%$ & $31.9 \%$ \\
\hline $\begin{array}{l}\text { Questioning my professional competence } \\
\text { for every task I do. }\end{array}$ & 374 & $37.4 \%$ & $23.5 \%$ \\
\hline $\begin{array}{l}\text { Holding me alone responsible for the } \\
\text { negative results of work carried out by } \\
\text { others. }\end{array}$ & 355 & $35.5 \%$ & $28.7 \%$ \\
\hline $\begin{array}{l}\text { Being forced to do a job that will negatively } \\
\text { affect my self-confidence. }\end{array}$ & 328 & $32.8 \%$ & $33.2 \%$ \\
\hline Repeated reminders of my blunders. & 323 & $32.3 \%$ & $21.7 \%$ \\
\hline $\begin{array}{l}\text { Being deprived of responsibility or work } \\
\text { tasks. }\end{array}$ & 317 & $31.7 \%$ & $20.5 \%$ \\
\hline $\begin{array}{l}\text { Considering the work I do to be worthless } \\
\text { and unimportant. }\end{array}$ & 311 & $31.1 \%$ & $25.4 \%$ \\
\hline $\begin{array}{l}\text { Being ordered to do work below my level of } \\
\text { competence. }\end{array}$ & 311 & $31.1 \%$ & $24.4 \%$ \\
\hline $\begin{array}{l}\text { Exploitation at work, such as private } \\
\text { errands. }\end{array}$ & 249 & $24.9 \%$ & $25.7 \%$ \\
\hline
\end{tabular}

* Regularly: frequently and constantly on the scale.

**The ' $n$ ' in this column depends on the number of respondents who were victims, thus indicated in column 2 above.

The most common acts of WPB related to undermining the professional status of the victims are: constantly evaluating the victim's performance (54.2\%); making the victim responsible for more work than he or she can manage (54.1\%); and constantly finding mistakes/errors in victims' work and the results of the victim's work (47.6\%). The first two were also the acts that were the most regularly experienced by the victims - nearly a third of the victims indicated that they experience it frequently or constantly. The act least experienced by respondents is exploitation at work, such as private errands (24.9\%).

Table 5 shows respondents' exposure to eleven acts aimed at undermining the victim as a person. 
Table 5: Respondents who experienced behaviour undermining the victim as a person

\begin{tabular}{|l|l|l|l|}
\hline Act & $\begin{array}{l}\text { Number of } \\
\text { respondents who } \\
\text { were victims } \\
\text { (n=999) }\end{array}$ & $\begin{array}{l}\text { Percentage of } \\
\text { respondents who } \\
\text { were victims } \\
\text { (n=999) }\end{array}$ & $\begin{array}{l}\text { Percentage of } \\
\text { victims who were } \\
\text { regularly* exposed } \\
\text { to act** }\end{array}$ \\
\hline Having untrue things said about me. & 445 & $44.9 \%$ & $25.4 \%$ \\
\hline $\begin{array}{l}\text { Talking about me in a degrading and } \\
\text { dishonourable manner in front of others. }\end{array}$ & 359 & $36.3 \%$ & $29.0 \%$ \\
\hline $\begin{array}{l}\text { Starting untrue rumours about my private } \\
\text { life. }\end{array}$ & 332 & $33.7 \%$ & $29.2 \%$ \\
\hline Questioning my honesty and reliability. & 313 & $32.2 \%$ & $22.4 \%$ \\
\hline Making verbal threats to harm me. & 293 & $29.9 \%$ & $28.0 \%$ \\
\hline $\begin{array}{l}\text { Devaluation of my 'rights' and opinions with } \\
\text { reference to my age. }\end{array}$ & 257 & $26.7 \%$ & $21.8 \%$ \\
\hline $\begin{array}{l}\text { Facing behaviour such as colleagues } \\
\text { slamming their fist on the table. }\end{array}$ & 224 & $23.2 \%$ & $25.9 \%$ \\
\hline Writing unfair reports about me. & 223 & $22.8 \%$ & $26.5 \%$ \\
\hline Insulting and teasing me. & 219 & $22.3 \%$ & $23.7 \%$ \\
\hline $\begin{array}{l}\text { Devaluation of my 'rights' and opinion with } \\
\text { reference to my gender. }\end{array}$ & 210 & $21.4 \%$ & $26.2 \%$ \\
\hline $\begin{array}{l}\text { Suggesting that my mental health is not } \\
\text { sound. }\end{array}$ & 177 & $18.0 \%$ & $26.6 \%$ \\
\hline
\end{tabular}

* Regularly: frequently and constantly on the scale.

**The ' $n$ ' in this column depends on the number of respondents who were victims, thus indicated in column 2 above.

The most common act, in the category of victims experiencing behaviour that undermines them as persons, is victims having untrue things said about them: $44.9 \%$ of the respondents indicated that they experienced this negative behaviour during the 12 months preceding the survey, and $25.4 \%$ regularly experienced bullies spreading lies about them. The second most common negative act that undermines the person of the victim was perpetrators talking about them in a degrading and dishonourable manner in front of others (36.3\%); $29 \%$ of the victims experienced this degrading form of verbal abuse on a regular basis. The least common act in this category is perpetrators suggesting that the victim's mental health is not sound (18.0\%).

The last WPB category is bullying that comprises direct negative behaviour. This was measured with six statements on the questionnaire; the data are summarised in Table 6.

Table 6: Respondents who experienced direct negative behaviour

\begin{tabular}{|l|l|l|l|}
\hline Act & $\begin{array}{l}\text { Number of } \\
\text { respondents who } \\
\text { were victims } \\
\text { (n=999) }\end{array}$ & $\begin{array}{l}\text { Percentage of } \\
\text { respondents who } \\
\text { were victims } \\
\text { (n=999) }\end{array}$ & $\begin{array}{l}\text { Percentage of } \\
\text { victims who were } \\
\text { regularly* exposed } \\
\text { to act** }\end{array}$ \\
\hline $\begin{array}{l}\text { Purposefully leaving when I enter a worksite } \\
\text { (e.g. staffroom, office or classroom). }\end{array}$ & 221 & $22.4 \%$ & $21.3 \%$ \\
\hline $\begin{array}{l}\text { Preventing or forbidding colleagues from } \\
\text { talking to me. }\end{array}$ & 217 & $22.0 \%$ & $24.0 \%$ \\
\hline Verbal abuse (e.g. insults, slander). & 173 & $17.6 \%$ & $22.5 \%$ \\
\hline Ridicule. & 161 & $16.7 \%$ & $26.1 \%$ \\
\hline Having my personal possessions damaged. & 145 & $14.8 \%$ & $17.9 \%$ \\
\hline Having physical violence used against me. & 116 & $11.7 \%$ & $19.0 \%$ \\
\hline
\end{tabular}

* Regularly: frequently and constantly on the scale.

**The ' $n$ ' in this column depends on the number of respondents who were victims, thus indicated in column 2 above. 
Direct, negative behaviour that is most commonly experienced by respondents is others purposefully leaving when the victim enters a worksite (22.4\%). Of these 221 respondents, $21.3 \%$ indicated that they experience direct shunning regularly. The act that was indicated to be experienced most regularly by victims $(26.1 \%)$, albeit by less respondents $(16.7 \%)$, was to be ridiculed.

\section{Discussion}

The aim of this study is to contribute to the limited body of knowledge on the prevalence of WPB within the international and South African schooling context. Using a self-reporting questionnaire this study exposed the commonness of WPB among participating teachers: $90.8 \%$ of the respondents were victims of WPB during the 12 months that preceded the study, and $89.1 \%$ of the victims had been exposed to at least two different types of WPB. The perpetrators especially tried to undermine the victims' professional status $(83.8 \%)$ and isolate them $(80.8 \%)$. The study furthermore identified the following as the three most common negative acts experienced by the respondents: constantly evaluating their performance (54.2\%); making them responsible for more work than they can manage (54.1\%); and constantly finding mistakes/errors in their work and the results of their work (47.6\%). The study moreover revealed that victims of WPB were most frequently or constantly exposed to the following three negative acts: making them responsible for more work than they can manage (32.8\%); constantly evaluating their performance (32.7\%); and being forced to do a job that would negatively affect their self-confidence (33.2\%).

As with victims of WPB within and outside the teaching fraternity, teachers who participated in our study were subjected to a diverse range of bullying which has been reported in the literature. These reported prevalence rates differ between studies. This can be explained by differences in study populations, definitions, the number of items (acts) listed, whether or not acts are clustered into categories/types of WPB, different response categories and different timeframes. The subsequent discussion of our results and attempts to place it within the broader body of local and international research on WPB, should therefore be read with caution.

Quantitative studies on WPB within the South African context have shown that workers across occupations have been exposed to bullying. The percentages of respondents who indicated that they were victims of WPB varies between 77.8\% in Marais-Steinmann's 19981999 study across occupations (Marais-Steinmann, 2003:9) to 19\% in the study by Upton (2010:57) on WPB among workers of a large construction company. If these percentages are compared with the findings of our study, namely that $90.8 \%$ of the respondents indicated that they were victims of at least one act of WPB, our study affirms Blasé et al.'s (2008:264) assertion that teaching is a high-risk occupation. However, when comparing the $90.8 \%$ with available statistics on the prevalence rates of WPB in schools in Croatia (22.4\%) (Russo et al., 2008:545), Lithuania (25.4\%) (Malinauskienë et al., 2005:22), Turkey (50\%) (Cemaloğlu, 2007a:792), Norway (8.9\%) (Zapf et al., 2011:93) and the UK (76\%) (NASUWT, 2012:8), it seems as if WPB in an extremely serious problem in some South African schools, compared to the occurrence in other countries. The underlying reasons for the high prevalence rates should be sought within the South African context: South African teachers are working in 'toxic' schools characterised by disgruntled, overworked and stressed teachers (Kirsten et al., 2005:12), high levels of learner-on-learner and learner-on-educator violence and bullying, communities fraught with moral degradation, racial conflict, violence, lawlessness and 
economic despair (De Wet, 2010:1450-1451). In schools where despair and disrespect prevail, teachers often turn on one another.

Despite our reservations of comparing our results on the prevalence of WPB with other research, it should be noted that a comparison of our study's five most-frequently reported bullying behaviours with the most common types of negative behaviour described in other WPB studies, reveals similarities. Behaviours such as "constantly evaluating my performance"; "making me responsible for more work than I can manage"; "constantly finding mistakes/errors in my work"; "behaving as if I am not seen or not there in the school environment"; and "making me feel as if my work and I are being inspected" also appears to be frequently encountered behaviours in other studies (e.g. Cemaloğlu, 2007a:794; Yildirim et al., 2007:452). We, moreover, found that most of the respondents were subjected to the following three types of negative behaviour: behaviour aimed at undermining their professional status (83.8\%); isolating them (80.8\%); and undermining them as a person (66.3\%). Some of these results are comparable to those of Yildirim et al. (2007:452). Their study revealed that the nurses who took part in their study were mostly subjected to behaviour aimed at undermining their professional status (85\%). Large percentages of the victims were also subjected to behaviour aimed at undermining them as persons (82\%). The similarities between the results, despite the demographic differences (particularly countries and occupations), may be attributed to the sameness in the categorisation and predetermined acts of bullying in the questionnaires used. The latter emphasise the need for greater coherence in survey instruments. Standardised survey instruments are available (cf. Nielsen et al., 2011:154-159).

A finding of this study, namely that direct, negative behaviour, such as having personal possessions damaged and the use of physical violence against a respondent, are not common WPB acts in schools, confirm findings of other research on WPB in the workforce in general (Yildirim et al., 2007:453; Zapf et al., 2011:88), as well as in schools (Blasé et al., 2008:291; Cemaloğlu, 2007a:794). This finding supports the assumption that WPB is primarily a form of psychological rather than physical aggression (Zapf et al., 2011:88).

This study reveals that teachers, who are bullied, tend to experience a large number of bullying behaviours from different categories of bullying (Table 2). This is consistent with previous research (cf. Zapf et al., 2011:88) and supports the theory that individual antecedents such as the personality of the bully and victim be may causes for WPB (Glasø, Matthiesen, Nielsen \& Einarsen, 2007:314; Zapf, 1999:78). Victims of bullying tend to be more anxious and neurotic and less agreeable, contentious and extrovert than non-victims (Glasø et al., 2007:314).

\section{Limitations of the study}

The contributions of this study should be viewed in the light of several limitations: (1) This sample is not representative of the South African teaching fraternity, due to the overrepresentation of female respondents, and the non-representative geographical distribution. All the respondents were, moreover, teachers who were in process of upgrading their qualifications. This implies that all the respondents - at the time of completing the questionnaires - did not comply with the National Policy Framework for Teacher Education and Development in South Africa which specifies that all teachers must have a degree (Cosser, Kraak \& Winnaar, 2011:32). Although this does not interfere with the aims of our study, the results cannot be generalised. (2) The issue of sample bias should also be 
considered, given the nature of the sample (e.g. the low response rate), particularly in terms of those who chose to - or not to - participate in the research on a relatively emotional topic (Agervold, 2007:170; Christophersen, Elstad \& Turmo, 2011:650; McCormack et al., 2009:2120). The low response rate may thus have harmed the integrity of the study, because it may be believed that persons who have experienced bullying themselves or who have been affected by it will be more likely to participate in such a study, than those people who have never been in contact with the phenomenon (Agervold, 2007:170). (3) We used a single measure instrument (self-rated questionnaire). More measures and more sources would have provided more reliable data (cf. Russo et al., 2008:550). (4) The questionnaire included acts that cannot, according to Agervold (2007:170) be "unequivocally described as bullying", such as, withholding information, being given tasks with impossible targets and deadlines, and given tasks below a teacher's level of competence. Agervold (2007:170) argues in this regard that being exposed to unmanageable workloads is a common experience today, without this necessarily being related to bullying. He believes that such acts or situations can only be related to bullying in an objective sense within the wide margins of uncertainty, given that they all form part of the traditional management routines in modern organisations. (5) A further limitation of this study is the use of self-reported questionnaire data. According to Christophersen et al. (2011:650) the subjective component of such data is indisputable. Independent judgement could provide interesting data on whether or not managers acted maliciously, because of the fine line between good management practices and what may be perceived as acts of WPB (cf. Agervold, 2007:170). It will, however, be difficult to carry out this process while honouring promises of anonymity.

\section{Conclusion}

Despite its limitations, this study adds to the limited body of knowledge on WPB among teachers worldwide, and to our understanding of WPB in a high risk occupation in a country whose education system has been called "a national disaster" (Bloch, 2009:58). Teachers are key role-players in rescuing the failing education system. Yet, statistics suggest that they are emotionally destroying one another, rather than working together for the greater good. Thus, there is a pressing need to address WPB in South African schools. Policies to address WPB should however, not be limited to teachers, but should embrace all employees in South Africa. South African labour legislation lacks an explicit definition of workplace bullying (Le Roux, Rycroft \& Orleyn, 2010:53). These policies need to be institutionalised and procedures put in place for reporting and investigating incidents of WPB. The training of all employees should be implemented for the purpose of recognising, dealing with and preventing WPB.

\section{References}

Agervold, M. (2007). Bullying at work: a discussion of definitions and prevalence, based on an empirical study. Scandinavian Journal of Psychology, 48:161-172.

Birkbech University of London. n.d. Definitions of bullying, harassment and victimisation. Available http://www.bbk.ac.uk/hr/policies_services/Dignity_at_work_and_study/guide/definiti ons (accessed on 27 November 2013).

Blasé, J. \& Blasé, J. (2004a). The dark side of school leadership: implications for administrator preparation. Leadership and Policy in Schools, 3(4):245-273. 
Blasé, J. \& Blasé, J. (2004b). School principal mistreatment of teachers: teachers' perspectives on emotional abuse. Journal of Emotional Abuse, 4(3/4):151-175.

Blasé, J., Blasé, J. \& Du, F. (2008). The mistreated teacher: a national study. Journal of Educational Administration, 3:263-301.

Bloch, G. (2009). The toxic mix. What's wrong with South Africa's schools and how to fix it. Cape Town: Tafelberg.

Cemaloğlu, N. (2007a). The exposure of primary school teachers to bullying: an analysis of various variables. Social Behaviour and Personality, 35(6):789-802.

Cemaloğlu, N. (2007b). Relationship between organizational learning and workplace bullying in learning organisations. Educational Research Quarterly, 33(3):3-38.

Christophersen, K., Elstad, E. \& Turmo, A. (2011). The nature of social practice among school professionals: consequences of the academic pressure exerted by teachers in their teaching. Scandinavian Journal of Educational Research, 55(6):639-654.

Cosser, M., Kraak, A. \& Winnaar, L. (2011). Further Education and Training (FET) Colleges at a glance in 2010. Pretoria: HSRC.

Cunniff, L. \& Mostert, K. (2012). Prevalence of workplace bullying of South African employees. South African Journal of Human Resource Management, 10(1):1-15.

Denton, J.M. \& Van Lill, J.B. (2007). Phenomenological experience of workplace bullying. World Journal of Management Eं Economics, 1(1):28-41.

De Vos, J. (2013). Teachers' experiences of workplace bullying and its effects on health: developing a multi-level intervention programme. Unpublished doctoral thesis, Northwest University, Potchefstroom, South Africa.

De Wet, C. (2010). The reasons for and the impact of principal-on-teacher bullying on the victims' private and professional lives. Teaching and Teacher Education, 26:1450-1459.

De Wet, C. (2011). The professional lives of teacher victims of workplace bullying: a narrative analysis. Perspectives in Education 29(4):66-77.

Duffy, M. \& Sperry, L. (2007) Workplace mobbing: individual and family health consequences. The Family Journal, 15(4):398-404.

Einarsen, S. (1999). The nature and causes of bullying at work. International Journal of Manpower, 20:16-27.

Einarsen, S., Raknes, B.I. \& Matthiesen, S.B. (1994). Bullying and harassment at work and their relationships to work environment quality: An exploratory study. European Work and Organizational Psychologist, 4(4):381-401.

Ertük, A. (2013). Mobbing behaviour: victims and the affected. Education Science: Theory $\Xi^{\circ}$ Practice, 13(1):169-173.

Fahie, D. \& Devine, D. (2012). The impact of workplace bullying on primary school teachers and principals. Scandinavian Journal of Educational Research. Available at: DOI:10.1080/00313831.2012.725099. Retrieved 24 May 2013.

Glasø, L., Matthiesen, S.B., Nielsen, M.B. \& Einarsen, S. (2007). Do targets of workplace bullying portray a general victim personality profile? Scandinavian Journal of Psychology, 48:313-319. 
Jansen, J. (2011). Great South African teachers. Johannesburg: Bookstorm.

Hauge, L.J., Skogstad, A. \& Einarsen, S. (2007). Relationships between stressful work environments and bullying: results of a large representative study. Work E Stress, 21(3):220-242.

Jennifer, D., Cowie, H. \& Ananiadou, K. (2003). Perceptions and experiences of workplace bullying in different working populations. Aggressive Behaviour, 29:489-496.

Khalil, D. (2009). Levels of violence among nurses in Cape Town public hospitals. Nursing Forum, 44(3):207-217.

Kirsten, G.J.C., Viljoen, C.T. \& Rossouw, J.P. (2005) Bullying by educational managers with narcissistic personality disorder: a health protection and psycho-legal issue? Paper presented at the meeting of the South African Education Law and Policy Association (SAELPA), Bloemfontein, South Africa.

Le Roux, R., Rycroft, A. \& Orleyn, T. (2010). Harassment in the workplace: law, policies and processes. Durban: LexisNexis.

Leymann, H. (1996). The content and development of mobbing at work. European Journal of Work and Organizational Psychology, 5(2):165-184.

Malinauskienë, V., Obelenis, V. \& Đopagienë, D. (2005). Psychological terror at work and cardiovascular diseases among teachers. Acta Medica Lituanica, 12(2):20-25.

Marais-Steinman, S. (1998). The changing workplace: work trauma and the workplace. Cape Town: Kagiso Publishers.

Marais-Steinman, S. (2003). Workplace violence in the health sector. Country case study: South Africa. Joint programme on workplace violence in the health sector, International Labour Organisation (ILO), International Council of Nurses (ICN), World Health Organisation (WHO) and Public Service International (PSI). $\begin{array}{lllll}\text { Retrieved } & 15 & \text { May } & 2011\end{array}$ www.who.int/violence.../violence/.../en/WV countrystudysouthafrica.pdf.

McCormack, D., Casimir, G., Djurkovic, N. \& Yang, L. (2009). Workplace bullying and intention to leave among schoolteachers in China: the mediating effect of affective commitment. Journal of Applied Social Psychology, 39(9):2106-2127.

Moayed, F.A., Daraiseh, N., Shell, R. \& Salem, S. (2006). Workplace bullying: a systematic review of risk factors and outcomes. Theoretical Issues in Ergonomics Sciences, 7(3):311327.

Momberg, M.A. (2011). The prevalence and consequences of workplace bullying in South Africa. Unpublished Master's dissertation, Nelson Mandela Metropolitan University, Port Elizabeth, South Africa.

Naidoo, K. (2000). Bullies at work. Human Resource Future, 1:30-31.

NASUWT (National Association of Schoolmasters Union of Women Teachers). (2012). Workplace bullying in schools and colleges. Birmingham: NASUWT.

Nielsen, M.B., Notelaers, G. \& Einarsen, S. (2011). Measuring exposure to workplace bullying. In S Einarsen, H Hoel, D Zapf \& C.L. Cooper (Eds.), Bullying and harassment in the workplace (pp. 149-174). Boca Raton, CL: Taylor \& Francis,. 
Notelaers, G., Einarsen. S., De Witte, H. \& Vermunt, J.K. (2006). Measuring exposure to bullying at work: The validity and advantages of the latent class cluster approach. Stress E Work, 20(4):289-302.

Ozturk, H., Sokmen, S., Yilmaz, F. \& Cillingir, D. (2008). Measuring mobbing experiences of academic nurses: developing a mobbing scale. Journal of American Academy of Nurse Practitioners, 20:435-442.

Pietersen, C. (2007). Interpersonal bullying behaviours in the workplace. South African Journal of Industrial Psychology, 33(1):59-66.

Pietersen, J. \& Maree, K. (2007). Standardisation of a questionnaire. In K. Maree (Ed.) First steps in research (pp215-223). Pretoria: Van Schaik.

Rayner, C., Hoel, H. \& Cooper, C.L. (2002). Workplace bullying. London: Taylor \& Francis.

Russo, A., Millić, R., Knežević, B., Mullić, R. \& Mustajbegović, J. (2008). Harassment in workplace among school teachers: development of a survey. Croatian Medical Journal, 49:545-552.

Rutherford, R.M. (2009). A creativity development model to enhance educator security - a labour law perspective. Unpublished doctoral thesis, Northwest University, Potchefstroom, South Africa.

Salin, D. (2003). Ways of explaining workplace bullying: a review of enabling, motivating and precipitating structures and processes in the work environment. Human Relations, 56(10):1213-1232.

Santos, J.R.A. (1999). Cronbach's Alpha: A tool for assessing the reliability of scales. Journal of Extension 37(2). Retrieved May 23, 2013, from http://www.joe.org/joe/1999april/tt3.html.

Samnani, A. (2013). Embracing new directions in workplace bullying research: a paradigmatic approach. Journal of Management Inquiry, 22(1):26-36.

Smith, P.K., Singer, M., Hoel, H. \& Cooper, C.L. (2003). Victimisation in the school and the workplace: are there any links? British Journal of Psychology, 94:175-188.

Upton, L. (2010). The impact of workplace bullying on individual and organisational wellbeing in a South African context and the role of coping as a moderator in the bullyingwell-being relationship. Unpublished Master's dissertation, University of the Witwatersrand, Johannesburg, South Africa.

Yildirim, D., Yildirim, A. \& Timucin, A. (2007). Mobbing behaviours encountered by nurse teaching staff. Nursing Etbics, 14(4):447-463.

Zapf, D. (1999). Organisational, work group related and personal causes of mobbing/bullying at work. International Journal of Manpower, 20(1/2):70-85.

Zapf, D. \& Einarsen, S. (2001). Bullying in the workplace: recent trends in research and practice - an introduction. European Journal of Work and Organizational Psychology, 10(4):369-373.

Zapf, D., Escartin, J., Einarsen, S., Hoel, H. \& Vartia, M. (2011). Empirical findings on prevalence and risk groups of bullying in the workplace. In S. Einarsen, H. Hoel, D Zapf \& C.L. Cooper (Eds.), Bullying and harassment in the workplace (pp. 75-195). Boca Raton, CL: Taylor \& Francis. 